in 1871 , and was placed second in the first class of the Natural Science Tripos. Joining the Geological Survey of India in 1874 , he began his scientific career in the mountains of Kashmir, of which he made a successful pioneer geological exploration. While there his opportunities for sport continued to foster his interest in zoology, and he soon acquired a good knowledge of the mammals and birds of the country. The great collection of Tertiary mammalian remains in the Indian Museum at Calcutta then attracted his attention, and he began a systematic study of these fossils, which he described in the Palaeontologia Indica.

With little material for comparison in India, and needing the corresponding collections in the British Museum for reference, Mr. Lydekker soon recognised the necessity of returning to London if his work was to be exhaustive. $\mathrm{He}$ accordingly retired from the Indian Survey in 1882 , had the fossils from Calcutta sent in instalments to London, and by 1887 had completed the fine series of volumes describing not only the Siwalik Vertebrata, but also the pre-Tertiary Vertebrata of India. At the same time, between 1885 and 1887 , Mr. Lydekker prepared for the British Museum a catalogue of the fossil mammals in the department of geology (in five parts), which was followed by similar catalogues of the fossil reptiles and amphibians (four parts, I888-9o), and fossil birds (one part, I89r). Though presenting only a somewhat hasty and superficial view of the subject, these catalogues were at the time of real utility; and they are noteworthy as the first systematic attempt to correlate the European with the more recently discovered American fossils.

In 1893, and again in 1894, Mr. Lydekker visited the Argentine Republic and spent some months in studying the wonderful collection of fossil vertebrates in the La Plata Museum. His work was published in two handsomely illustrated volumes ("Anales del Museo de La Plata," tomos II., III.), and gave the first satisfactory account of several of the peculiar extinct vertebrates of South America. His descriptions of ancestral Vetacea from the Tertiary, and Dinosaurian remains from the Cretaceous, formations are especially valuable. The visits to South America led Mr. Lydekker to appreciate more thoroughly the need for considering the evidence of fossils when dealing with questions of geographical distribution, and in 1896 he published a "Geographical History of Mammals," which is in many respects his most original and important work.

While occupied with purely scientific research, Mr. Lydekker did not overlook the needs of ordinary students, amateurs, and sportsmen, and during his later years most of his numerous writings were adapted for their use. So long ago as 1889 he contributed the volume on vertebrates to the third edition of Nicholson's "Manual of Palæontology," and in I89x he co-operated with Sir William Flower in "An Introduction to the Study of Mammals." Between I893 and 1896 he also edited the "Royal Natural History," and wrote the section on vertebrata. Work of this kind was facilitated by his occupation at the British Museum in arranging the exhibited collections of mammals and reptiles in the department of zoology, where he was employed from $\mathbf{1} 896$ until the time of his death. He not only arranged the collections in an admirable manner, but also prepared several valuable guide-books. His last work was a catalogue of Ungulate mammals in the British Museum, of which three parts were published, and the fourth, completing the Artiodactyla, was left by him nearly ready for issue.

Mr. Lydekker was elected a Fellow of the Royal Society in I894, and was awarded the Lyell Medal by the Geological Society in 1902.

\section{DR. W. J. SELL, F.R.S.}

W ILLIAM JAMES SELL, university lecturer and senior demonstrator in chemistry at the University of Cambridge, died at Cambridge after a long illness on March 7 . He was born at Cambridge in 1847 , and for more than fifty years was connected with the chemical laboratories there, and contributed in no small degree to their development and success. He was barely fifteen when, on the recommendation of the master of the elementary school which he attended, he was employed at the chemical laboratory of St. John's College, at that time the only one in the University open to undergraduates. Here he learnt elementary analysis and the use of apparatus, heard the professor's lectures, and saw his experiments. He made good use of his opportunities, and soon made himself an efficient assistant. In 1865, when the Jacksonian professor of natural philosophy removed his apparatus into a new building, the room vacated by him was united with that of the professor of chemistry, and a room built above them for a students' laboratory, the first step taken by the University, in its corporate capacity as distinct from the colleges; to provide experimental training for its students. Here Sell was appointed attendant, and had charge of the apparatus, and not only assisted the professor in the experiments at his lectures, which at that time embraced physics as well as chemistry proper; but was much in demand to help the students, whose notions of making experiments were often crude. The laboratory was a poor place at.best in comparison with modern laboratories, but it grew and became filled with students, to which result Sell's help contributed not a little.

In I870 Sell married, and soon after entered Christ's College and matriculated in the University. He had acquired a good knowledge of chemistry, and of some other branches of natural science, and knew a little of modern languages, but no degree could be obtained at Cambridge without some acquaintance with Latin and Greek, and he had not learnt either. It was a formidable task to begin now, but he faced it with his usual quiet determination, studying: Latin and Greek at all times when his duties at the labora-

No. 2374, voL. 95] 
tory permitted, passed the examination in both languages, and was then able to take the Natural Sciences Tripos for his B.A. degree. In this he obtained a first class in honours for chemistry in 1876. This success brought him private pupils, and therewith an increased income, very necessary for him because University posts were all meagrely paid; at the same time he took a demonstratorship instead of remaining assistant to the professor. A short time afterwards he succeeded to the place of principal demonstrator.

Although Sell's position in the University, thenceforward to the end of his life, was that of a demonstrator, it must not be supposed that his public teaching was confined to what is usually known as demonstrating, which is mainly done by the junior members of the staff. On the contrary, inasmuch as chemical science was constantly expanding and learners increasing in number, the lectures had to be more specialised and the classes subdivided. The University had not the means to multiply the professors, and so the staff of the laboratory had to meet the demand for more instruction as best they could amongst themselves. In this Sell was most serviceable. He shirked nothing so that the teaching might, so far as lay in his power, keep pace with the growth of knowledge, and for many years was in reality an effective professor, though in name only demonstrator. He was never what is called a brilliant lecturer, but was a sound teacher, who gained the confidence of his hearers, and attracted them by his painstaking sincerity and willingness to help anyone in difficulty.

Sell had been elected a Fellow of the Royal Society of London in I90o, and took the degree of Sc.D. at Cambridge in rgo6. An attempt was made to get him promoted to the rank of reader in chemistry. The University has full power to do that, and there were similar applications in connection with other branches of learning, and Sell's friends thought that his distinction as a chemist, and his long and faithful devotion to the service of the University, gave him a claim to promotion at that time before any other aspirant to the same rank. The appointment of readers, however, does not rest with the University at large, but with a board composed of representatives of the various departments of knowledge, literary as well as scientific-in fact, with a body of specialists chosen as such. As always happens in such cases, every member of the board thinks that his foremost duty is to see that his own particular subject of study gets its share of money and places, and magnifies it accordingly, so that the board scarcely ever pulls together for the general advantage, still less to do justice to an individual. No readership was created at that time, and all the recognition Sell got was his appointment to a University lectureship with a stipend of 5 ol. a year.

In his younger days, when it was as much as he could do to maintain his family, he could scarcely spare time for original investigations; but later, when the laboratory was grown up and needed NO. 2374, VOL. 95] less nursing, he was able to show that he had the capacity for successful research and the will to advance knowledge himself, quite as much as to put others in the way of doing it. He will be best known by his work on pyridine derivatives, to which he was led by previous studies of citrazinic acid. These were the subjects of a large number of communications to the Chemical Society from 1892 onwards. In some of these researches he was assisted by one or other of the advanced students in the laboratory, while in other cases he worked alone. Without going into details, it may be mentioned that from pyridine he obtained eight distinct chloro-derivatives, and from pyridine hydrochloride, in addition, some remarkable dipyridyl compounds. Moreover, he did not fail to demonstrate the chemical constitution of most of the new compounds he discovered. Other subjects of interest investigated by him were the salts of a base containing chromium and urea, and colloid solutions of phosphates. All he did bore the stamp of careful accuracy, and he impressed on his pupils the necessity for sparing no pains to ensure this, if any real advance of knowledge were to be made.

$\mathrm{He}$ was so unassuming that only those who had known him long found how much was hidden under that modest behaviour. It really meant that he wished always to do what was right, whether convenient or inconvenient, and to believe other people to be as good as himself.

\section{NOTES.}

Dr. H. Kamerlingh Onnes, professor of experimental physics in the University of Leyden, has been awarded the Franklin medal of the Franklin Institute of Philadelphia.

IN spite of the war, the usual Dutch biennial congress of Science and Medicine was held this year, at Amsterdam, the first day being. April 8. In I9I7 the congress will meet at the Hague.

Dr. J. Alexander Murray has been appointed general superintendent of the Imperial Cancer Research Fund, and director of the laboratories, in succession to Dr. E. F. Bashford.

The Meteorological Office announces that Mr. J. E. Cullum retires from the post of superintendent of the Valencia Observatory, Cahirciveen, Co. Kerry, Ireland, and that Mr. L. H. G. Dines has been appointed to succeed him, as from May I. Mr. A. H. R. Goldie has been promoted senior professional assistant in succession to Mr. Dines at the observatory at Eskdalemuir.

AT the beginning of the war the Meteorological Office ceased the issue of weather charts to the newspapers. Announcement is now made that from May I the weather forecasts from the Meteorological Office for the several districts of the British Isles will not be available for publication. The only forecasts issued will be in what is known as the harvest weather forecast service. These are entirely local in character, and are telegraphed to agriculturists upon payment of the cost of the telegrams. 